\title{
MOX Fuel Alternatives for Minor Actinides Burnup in Thermal Spectrum
}

\author{
Martínez CE, Ramírez SJR*, Alonso G and Palacios HJ \\ Instituto Nacional de Investigaciones Nucleares, Nuclear Systems Department, Estado de México, México
}

${ }^{*}$ Corresponding author: Ramirez SJR, Instituto Nacional de Investigaciones Nucleares, Nuclear Systems Department, Carretera México-Toluca s/n, La Marquesa, Ocoyoacac, Estado de México, C.P. 52750, México, Fax: (+52) (55) 53297301, Tel: (+52) (55) 53297233, E-mail: ramon.ramirez@inin.gob.mx

Citation: Martínez CE, Ramírez SJR, Alonso G, Palacios HJ (2019) MOX Fuel Alternatives for Minor Actinides Burnup in Thermal Spectrum. J Waste Resour Recycl 1(1): 105. doi: 10.15744/2766-5887.1.105

Received Date: June 12, 2019 Accepted Date: August 27, 2019 Published Date: August 29, 2019

\begin{abstract}
The spent fuel from the nuclear power reactors is being stored in repositories and dry casks in many countries of the world. However, it does not solve the main problem of the spent fuel, which is the high radiotoxicity of fuel for a long term. A new strategy is required to close the nuclear fuel cycle, and for the sustainability of the nuclear power generation. This strategy could be the plutonium recycling to obtain more energy and recycle the Minor actinides produced during the irradiation, to transmute them into less radioactive products. In this work, we assess the amounts of Minor actinides generated in different fuel designs and the amounts of Minor actinides remaining after recycle them in a thermal reactor. First of all, it was performed a reference cell made of enriched uranium, later the fuel of this UOX fuel is changed to MOX fuel using depleted uranium as a matrix, were several plutonium concentrations were used to determine the amounts of minor actinides generated on each. Finally, an amount of Minor actinides was integrated into four rods of the new fuel assembly, and after the burnup simulation, the remaining amount of Minor actinides is determined. To determinate the reduction of minor actinides in the fuel, the initial and final inventories is checked. The results show that if the plutonium concentration in the fuel assembly is high, then the production of Minor actinides is high too. The calculations were made using the lattice code CASMO- 4 and the results obtained are shown in section 6 of this paper.
\end{abstract}

Keywords: MOX; Recycling; Closed Fuel Cycle; Actinides

\section{Introduction}

The idea of recycle the spent nuclear fuel is not new. Since the beginning of the nuclear era, the fuel reprocessing has been a fundamental part of plutonium recovery for the use of nuclear weapons. Later the plutonium has been used to fabricate fuels of mixed-oxide denoted as MOX fuels, this kind of fuel permits to obtain energy from plutonium fission, burning mainly the isotopes ${ }^{239} \mathrm{Pu}$ and ${ }^{241} \mathrm{Pu}$. This recycling of plutonium has given excellent results in the nuclear industry; nowadays the idea of actinides recycling is taken as part of the closed nuclear fuel cycle [1]. The minor actinides recycling in a thermal reactor would be viable if the amounts of actinides destroyed are significant, in this work, it is evaluated the amounts of minor actinides generated by different designs of fuel and their recycling almost in the same reactor where they were generated.

The recycling can be made mixing the minor actinides together with the fuel matrix in a way which we call "the island concept," in this fuel only 4rods of the entire fuel assembly will contain minor actinides. In all the actinides cases, 4 rods containing the fuel and $6 \%$ of minor actinides integrated as oxides were replaced as part of the fuel assembly. Seven different fuel cells were simulated to establish the amounts of minor actinides generated in the fresh fuel for three cases, later, other simulations were made to include a minor actinides concentration at the beginning of the fuel cycle; the outcomes are shown in section 5 .

The strategy used in this work was the following; first, it was necessary to establish the material of study for the actinides generation. This material was the commercial uranium oxide fuel and take it as a reference, then to design a MOX fuel cell. Starting with the uranium oxide fuel, this MOX design was made scaling the radial uranium enrichments to plutonium concentrations making use of a Fissile Material Ratio (FMR) which was found in previous work as the equivalent in a MOX fuel cycle. It is a relation between the uranium enrichments to concentrations of reactor grade plutonium, to obtain the MOX fuel cell [2]. In the MOX fuel cell, the gadolinium rods remains without changes as in the case of the UOX fuel assembly, with all this made we get a reference for the UOX and MOX fuel cells.

Taken the first MOX fuel cell as model, we replace eight fuel rods by water rods to increase the moderator to fuel ratio and determine the actinides production, the results obtained are shown in section 6.A flow diagram of the calculations made in this paper is shown in Figure 1. 


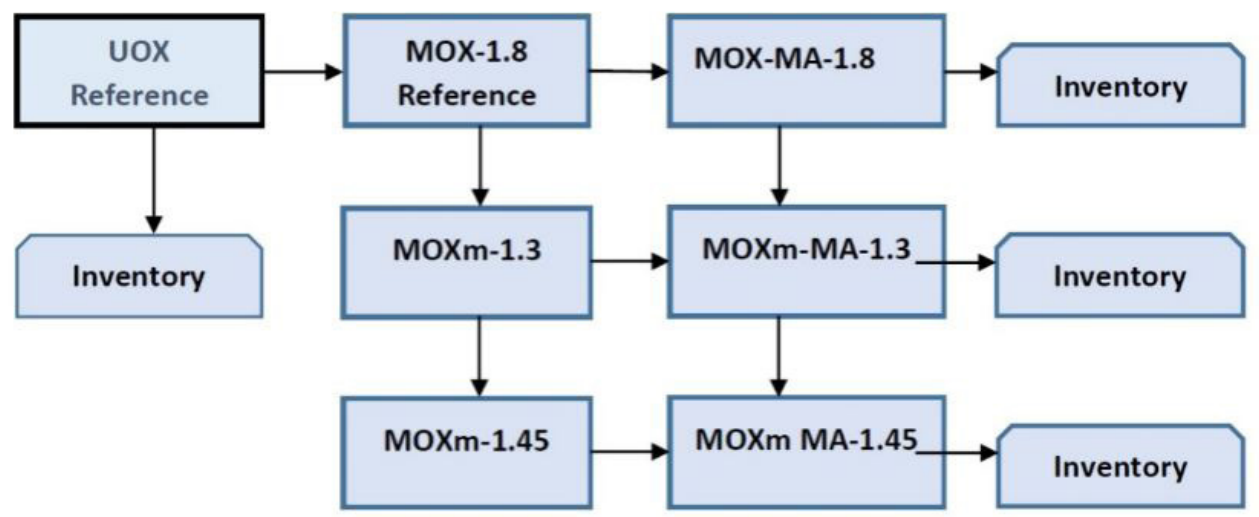

FMR = Fissile Material Ratio (uranium to plutonium reactor grade); UOX Reference: is a calculation to obtain the normal production of minor actinides; MOX 1.8 Reference: made scaling fissile uranium enrichments to plutonium concentrations; MOX MA-1.8: MOX Reference with minor actinides integrated in fuel (four rods); MOXm-1.3: Changes in scaling factor and moderation ratio FMR = 1.3; MOXm-MA-1.3: This case include four rods with $6 \%$ of minor actinides in the fuel; MOXm-1.45: Changes in scaling factor and moderation ratio FMR = 1.45; MOXm-MA-1.45: This case include four rods with $6 \%$ of minor actinides in the fuel

Figure 1: Flow diagram of calculation sequence

\section{UOX fuel cell reference}

The thermal reactor proposed for the irradiation is a BWR reactor, currently in operation at 2027 MWth with a fuel cycle length of 18 months, and an average fuel burnup of $47.5 \mathrm{GWd} / \mathrm{TU}$ during four power cycles.

\begin{tabular}{|c|c|c|c|c|c|}
\hline Material & Node & UOX & Enrichment & Length & Zone \\
\hline Reflector & \# & Cell & $\%$ & inch & \# \\
\hline Reflector & 25 & Type 6 & 0.71 & 6 & 6 \\
\hline \multirow{23}{*}{ FUEL } & 24 & Type 5 & 0.71 & 6 & 5 \\
\hline & 23 & \multirow{6}{*}{ Type 4} & \multirow{6}{*}{4.00} & \multirow{6}{*}{36} & \multirow{6}{*}{4} \\
\hline & 22 & & & & \\
\hline & 21 & & & & \\
\hline & 20 & & & & \\
\hline & 19 & & & & \\
\hline & 18 & & & & \\
\hline & 17 & \multirow{2}{*}{ Type 3} & \multirow{2}{*}{4.00} & \multirow{2}{*}{12} & \multirow{2}{*}{3} \\
\hline & 16 & & & & \\
\hline & 15 & \multirow{14}{*}{ Type 2} & \multirow{14}{*}{4.11} & \multirow{14}{*}{84} & \multirow{14}{*}{2} \\
\hline & 14 & & & & \\
\hline & 13 & & & & \\
\hline & 12 & & & & \\
\hline & 11 & & & & \\
\hline & 10 & & & & \\
\hline & 9 & & & & \\
\hline & 8 & & & & \\
\hline & 7 & & & & \\
\hline & 6 & & & & \\
\hline & 5 & & & & \\
\hline & 4 & & & & \\
\hline & 3 & & & & \\
\hline & 2 & & & & \\
\hline Reflector & 1 & Type 1 & 0.71 & 6 & 1 \\
\hline
\end{tabular}

As shown in Table 1, the fuel is composed of 25 nodes (6 inches each), which are divided into 6 zones, here zone is a length in which a type of cell can represent all the nodes specified in that zone. The zone 1 is natural uranium used as reflector (6 inches), the zone 2 is enriched uranium at $4.11 \%$ ( 84 inches), the zone 3 is uranium with $4 \%$ of enrichment ( 12 inches), the zone 4 consists of 6 
nodes (36 inches) with $4 \%$ of enrichment, and the zones 5 and 6 correspond to natural uranium used as a reflector (12 inches). So the power zone (2) was selected for the simulation. A reference cell calculation using the CASMO-4 code was performed [3], the axial length of this cell is composed of uranium enrichment fuel. The amount of heavy metal resulting in the cell was: $131.75 \mathrm{~kg}$.

\begin{tabular}{|c|c|c|c|c|c|c|c|c|c|}
\hline 2 & 2.8 & 3.6 & 4.4 & 4.4 & 4.4 & 3.95 & 3.6 & 2.8 & 2 \\
\hline 2.8 & 4.4 & 3.95 & 4.9 & 3.95 & 3.95 & 4.9 & 3.95 & 4.4 & 2.8 \\
\hline 3.6 & 3.95 & 4.4 & 3.95 & 4.4 & 4.9 & 4.4 & 4.4 & 3.95 & 3.95 \\
\hline 4.4 & 4.9 & 3.95 & 4.4 & 4.9 & $\mathrm{~W}$ & $\mathrm{~W}$ & 4.4 & 4.9 & 4.4 \\
\hline 4.4 & 3.95 & 4.4 & 4.9 & 4.4 & $\mathrm{~W}$ & $\mathrm{~W}$ & 4.4 & 4.4 & 4.4 \\
\hline 4.4 & 3.95 & 4.9 & $\mathrm{~W}$ & $\mathrm{~W}$ & 4.4 & 4.4 & 4.4 & 4.4 & 4.4 \\
\hline 3.95 & 4.9 & 4.4 & $\mathrm{~W}$ & $\mathrm{~W}$ & 4.4 & 4.4 & 4.4 & 4.9 & 4.4 \\
\hline 3.6 & 3.95 & 4.4 & 4.4 & 4.4 & 4.4 & 4.4 & 4.4 & 3.95 & 3.95 \\
\hline 2.8 & 4.4 & 3.95 & 4.9 & 4.4 & 4.4 & 4.9 & 3.95 & 4.4 & 3.6 \\
\hline 2 & 2.8 & 3.95 & 4.4 & 4.4 & 4.4 & 4.4 & 3.95 & 3.6 & 2 \\
\hline
\end{tabular}

Numbers inside the figure is uranium enrichment (percent weight)

Figure 2: UOX fuel cell used as reference in the actinides generation

The cell calculation was run to obtain a burn-up of $47.5 \mathrm{GWd} / \mathrm{TU}$ given a total amount of minor actinides of $0.06628 \%$ with respect to the total of heavy metals of the cell, which means around of $87.336 \mathrm{~g}$ of minor actinides, the actinides of our interest are mainly $\mathrm{Np}$, Am and $\mathrm{Cm}$. These actinides, generated during the normal burn-up cycle, will serve after reprocessing and partitioning to incorporate the minor actinides inside new fuel cells Figure 2.

\section{MOX fuel cells}

Taking as reference a common fuel assembly for BWR reactors, a new kind of MOX fuel has been designed to incorporate a certain amount of actinides and to calculate which it is the expected amount of actinides destructed or transmuted during the irradiation in a thermal reactor. First of all, it is important to evaluate in the design of MOX fuel, the amounts of actinides generated during the irradiation of the fuel. This will allow us to determine how much spent fuel is required to add in the new design of the MOX fuel cells [4] (Figure 3).

\begin{tabular}{|c|c|c|c|c|c|c|c|c|c|}
\hline 2 & 2.8 & 3.6 & 4.4 & 4.4 & 4.4 & 3.95 & 3.6 & 2.8 & 2 \\
\hline 2.8 & 4.4 & 3.95 & 4.9 & 3.95 & 3.95 & 4.9 & 3.95 & 4.4 & 2.8 \\
\hline 3.6 & 3.95 & 4.4 & 3.95 & 4.4 & 4.9 & 4.4 & 4.4 & 3.95 & 3.95 \\
\hline 4.4 & 4.9 & 3.95 & 4.4 & 4.9 & W & W & 4.4 & 4.9 & 4.4 \\
\hline 4.4 & 3.95 & 4.4 & 4.9 & 4.4 & W & W & 4.4 & 4.4 & 4.4 \\
\hline 4.4 & 3.95 & 4.9 & W & W & 4.4 & 4.4 & 4.4 & 4.4 & 4.4 \\
\hline 3.95 & 4.9 & 4.4 & W & W & 4.4 & 4.4 & 4.4 & 4.9 & 4.4 \\
\hline 3.6 & 3.95 & 4.4 & 4.4 & 4.4 & 4.4 & 4.4 & 4.4 & 3.95 & 3.95 \\
\hline 2.8 & 4.4 & 3.95 & 4.9 & 4.4 & 4.4 & 4.9 & 3.95 & 4.4 & 3.6 \\
\hline 2 & 2.8 & 3.95 & 4.4 & 4.4 & 4.4 & 4.4 & 3.95 & 3.6 & 2 \\
\hline
\end{tabular}

The numbers inside boxes represent Pu Concentration

Figure 3: MOX-1.8 fuel cell for a MOX fuel assembly 


\section{The concept MOX-MA}

Based on the UOX fuel, the concept MOX is designed by changing the fissile material in the fuel and conserving the geometry and structural component. One way to do this it is to scale the fissile uranium enrichment by substituting them by reactor grade plutonium concentrations, fordo this process, several FMR of the fissile material were tested. We chose the value of FMR $=1.8$ to determinate the fissile material in the fuel rods, except for the rods containing gadolinium, which remain with their initial uranium enrichment [2].

In the cell MOX-MA-1.8, the minor actinides (MA) were included by inserting four rods which contain $6 \%$ of minor actinides, mainly: ${ }^{237} \mathrm{~Np},{ }^{241} \mathrm{Am}$, and ${ }^{244} \mathrm{Cm}$ in a matrix of depleted uranium with enrichment tails of $0.25 \%{ }^{235} \mathrm{U}[5]$.

The minor actinides vector used to incorporate MA in the fuel rods; it is shown in Table 2:

\begin{tabular}{|c|c|c|c|}
\hline Isotope & ${ }^{237} \mathrm{~Np}$ & ${ }^{241} \mathrm{Am}$ & ${ }^{244} \mathrm{Cm}$ \\
\hline$\% \mathrm{~W}$ & 79.8045 & 8.3830 & 11.8125 \\
\hline
\end{tabular}
Table 2: The vector of the minor actinides

With these materials we have a new fuel cell of MOX-MA fuel; we can see in Figure 3 that this new fuel cell contains four rods with $6 \%$ of actinides incorporated into a uranium matrix.

\begin{tabular}{|l|l|l|l|l|l|l|l|l|l|}
\hline 3.60 & 5.04 & 6.48 & 7.92 & 7.92 & 7.92 & 7.11 & 6.48 & 5.04 & 3.60 \\
\hline 5.04 & 7.92 & AC & 8.82 & 7.11 & 7.11 & 8.82 & 7.11 & 7.92 & 5.04 \\
\hline 6.48 & AC & 4.40 & 7.11 & 4.40 & 8.82 & 7.92 & 4.40 & 7.11 & 7.11 \\
\hline 7.92 & 8.82 & 7.11 & 4.40 & 8.82 & $W$ & $W$ & 7.92 & 8.82 & 7.92 \\
\hline 7.92 & 7.11 & 4.40 & 8.82 & 7.92 & $W$ & $W$ & 4.40 & 7.92 & 7.92 \\
\hline 7.92 & 7.11 & 8.82 & $W$ & $W$ & 7.92 & 7.92 & 7.92 & 4.40 & 7.92 \\
\hline 7.11 & 8.82 & 7.92 & $W$ & $W$ & 7.92 & 7.92 & 4.40 & 8.82 & 7.92 \\
\hline 6.48 & 7.11 & 4.40 & 7.92 & 4.40 & 7.92 & 4.40 & 7.92 & 3.95 & AC \\
\hline 5.04 & 7.92 & 7.11 & 8.82 & 7.92 & 4.40 & 8.82 & 3.95 & 7.92 & 6.48 \\
\hline 3.60 & 5.04 & 7.11 & 7.92 & 7.92 & 7.92 & 7.92 & AC & 6.48 & 3.60 \\
\hline
\end{tabular}

Numbers inside are reactor grade Pu concentration

Figure 4: CellMOX-MA-1.8 of fuel containing rods with actinides

The main aims of these calculations are to determine the amounts of MA, generated in a fuel MOX. This fuel was simulated at the same burnup than the reference UOX fuel Figure 4.

\section{MOX fuel cell with a moderator to fuel ratio modified and with an FMR $=1.3$}

Previous studies on the change of the moderator to fuel ratio in an MOX fuel assembly gave results indicating that: If the amount of water in the fuel assembly is increased, it is possible to increase the limit number of MOX fuel assemblies in the core without violating the shutdown margin of the reactor [2].

This fuel cell contains eight positions of water rods, additional to the common water traps, so that it has a total of 16 positions with water rods.

This fuel cell has only MOX fuel rods without MA, but there are 16 water positions. Then we define this fuel cell as MOXm (Figure 5). 


\begin{tabular}{|l|l|l|l|l|l|l|l|l|l|}
\hline 2.60 & 3.64 & 4.68 & 5.72 & 5.72 & 5.72 & 5.14 & 4.68 & 3.64 & 2.60 \\
\hline 3.64 & 5.72 & 5.14 & 6.37 & $W$ & 5.14 & 6.37 & $W$ & 5.72 & 3.64 \\
\hline 4.68 & 5.14 & 4.40 & 5.14 & 4.40 & 6.37 & 5.72 & 4.40 & $W$ & 5.14 \\
\hline 5.72 & 6.37 & 5.14 & 4.40 & 6.37 & $W$ & $W$ & 5.72 & 6.37 & 5.72 \\
\hline 5.72 & $W$ & 4.40 & 6.37 & 5.72 & $W$ & $W$ & 4.40 & $W$ & 5.72 \\
\hline 5.72 & 5.14 & 6.37 & $W$ & $W$ & 5.72 & 5.72 & 5.72 & 4.40 & 5.72 \\
\hline 5.14 & 6.37 & 5.72 & $W$ & $W$ & 5.72 & 5.72 & 4.40 & 6.37 & 5.72 \\
\hline 4.68 & $W$ & 4.40 & 5.72 & 4.40 & 5.72 & 4.40 & 5.72 & 3.95 & 5.14 \\
\hline 3.64 & 5.72 & $W$ & 6.37 & $W$ & 4.40 & 6.37 & 3.95 & 5.72 & 4.68 \\
\hline 2.60 & 3.64 & 5.14 & 5.72 & 5.72 & 5.72 & 5.72 & 5.14 & 4.68 & 2.60 \\
\hline
\end{tabular}

The numbers inside are $\mathrm{Pu}$ concentration, without actinides load

Figure 5: Cell MOXm-1.3 fuel cell with 16 water rods and a FMR $=1.3$

The next fuel cell is similar to the prior but here, there are 4 rods containing $5.14 \%$ of plutonium as MOX fuel, these rods are replaced for new which contains $6 \%$ of MA in a depleted uranium matrix. With this we can define the new fuel cell as MOXm-AM (Figure 6).

\begin{tabular}{|l|l|l|l|l|l|l|l|l|l|}
\hline 2.60 & 3.64 & 4.68 & 5.72 & 5.72 & 5.72 & 5.14 & 4.68 & 3.64 & 2.60 \\
\hline 3.64 & 5.72 & Ac & 6.37 & W & 5.14 & 6.37 & W & 5.72 & 3.64 \\
\hline 4.68 & Ac & 4.40 & 5.14 & 4.40 & 6.37 & 5.72 & 4.40 & W & 5.14 \\
\hline 5.72 & 6.37 & 5.14 & 4.40 & 6.37 & $W$ & $W$ & 5.72 & 6.37 & 5.72 \\
\hline 5.72 & W & 4.40 & 6.37 & 5.72 & $W$ & $W$ & 4.40 & $W$ & 5.72 \\
\hline 5.72 & 5.14 & 6.37 & $W$ & $W$ & 5.72 & 5.72 & 5.72 & 4.40 & 5.72 \\
\hline 5.14 & 6.37 & 5.72 & $W$ & $W$ & 5.72 & 5.72 & 4.40 & 6.37 & 5.72 \\
\hline 4.68 & W & 4.40 & 5.72 & 4.40 & 5.72 & 4.40 & 5.72 & 3.95 & Ac \\
\hline 3.64 & 5.72 & W & 6.37 & W & 4.40 & 6.37 & 3.95 & 5.72 & 4.68 \\
\hline 2.60 & 3.64 & 5.14 & 5.72 & 5.72 & 5.72 & 5.72 & Ac & 4.68 & 2.60 \\
\hline
\end{tabular}

The numbers inside boxes represents, $\mathrm{Pu}$ concentration in the rods, $\mathrm{Ac}=$ actinides

Figure 6: Cell MOXm-MA-1.3 fuel with 16 water rods and a FMR $=1.3$

\section{MOXm fuel with a FMR $=1.45$}

This cell design was modified to increase the moderator to fuel ratio, replacing eight fuel rod for water rods inside the fuel assembly, a greater ratio of fissile material was used to determine the amounts of actinides produced during the irradiation for its posterior comparison with the reference case (Figure 7). 


\begin{tabular}{|l|l|l|l|l|l|l|l|l|l|}
\hline 2.90 & 4.06 & 5.22 & 6.38 & 6.38 & 6.38 & 5.73 & 5.22 & 4.06 & 2.90 \\
\hline 4.06 & 6.38 & 5.73 & 7.11 & $W$ & 5.73 & 7.11 & $W$ & 6.38 & 4.06 \\
\hline 5.22 & 5.73 & 4.40 & 5.73 & 4.40 & 7.11 & 6.38 & 4.40 & $W$ & 5.73 \\
\hline 6.38 & 7.11 & 5.73 & 4.40 & 7.11 & $W$ & $W$ & 6.38 & 7.11 & 6.38 \\
\hline 6.38 & $W$ & 4.40 & 7.11 & 6.38 & $W$ & $W$ & 4.40 & $W$ & 6.38 \\
\hline 5.73 & 5.73 & 7.11 & $W$ & $W$ & 6.38 & 6.38 & 6.38 & 4.40 & 6.38 \\
\hline 5.22 & 7.11 & 6.38 & $W$ & $W$ & 6.38 & 6.38 & 4.40 & 7.11 & 6.38 \\
\hline 5.22 & $W$ & 4.40 & 6.38 & 4.40 & 6.38 & 4.40 & 6.38 & 3.95 & 5.73 \\
\hline 4.06 & 6.38 & $W$ & 7.11 & $W$ & 4.40 & 7.11 & 3.95 & 6.38 & 5.22 \\
\hline 2.90 & 4.06 & 5.73 & 6.38 & 6.38 & 6.38 & 6.38 & 5.73 & 5.22 & 2.90 \\
\hline
\end{tabular}

The numbers inside boxes are $\mathrm{Pu}$ concentrations

Figure 7: MOXm-1.45 fuel cell with an FMR $=1.45$

The next fuel cell was made replacing 4 rods of MOX fuel containing $5.73 \%$ of plutonium per 4 rods containing $6 \%$ of actinides with the previously specified vector in a depleted uranium matrix [6] (Figure 8).

\begin{tabular}{|l|l|l|l|l|l|l|l|l|l|}
\hline 2.90 & 4.06 & 5.22 & 6.38 & 6.38 & 6.38 & 5.73 & 5.22 & 4.06 & 2.90 \\
\hline 4.06 & 6.38 & $\mathrm{Ac}$ & 7.11 & $\mathrm{~W}$ & 5.73 & 7.11 & $\mathrm{~W}$ & 6.38 & 4.06 \\
\hline 5.22 & $\mathrm{Ac}$ & 4.40 & 5.73 & 4.40 & 7.11 & 6.38 & 4.40 & $\mathrm{~W}$ & 5.73 \\
\hline 6.38 & 7.11 & 5.73 & 4.40 & 7.11 & $\mathrm{~W}$ & $\mathrm{~W}$ & 6.38 & 7.11 & 6.38 \\
\hline 6.38 & $\mathrm{~W}$ & 4.40 & 7.11 & 6.38 & $\mathrm{~W}$ & $\mathrm{~W}$ & 4.40 & $\mathrm{~W}$ & 6.38 \\
\hline 5.73 & 5.73 & 7.11 & $\mathrm{~W}$ & $\mathrm{~W}$ & 6.38 & 6.38 & 6.38 & 4.40 & 6.38 \\
\hline 5.22 & 7.11 & 6.38 & $\mathrm{~W}$ & $\mathrm{~W}$ & 6.38 & 6.38 & 4.40 & 7.11 & 6.38 \\
\hline 5.22 & $\mathrm{~W}$ & 4.40 & 6.38 & 4.40 & 6.38 & 4.40 & 6.38 & 3.95 & $\mathrm{Ac}$ \\
\hline 4.06 & 6.38 & $\mathrm{~W}$ & 7.11 & $\mathrm{~W}$ & 4.40 & 7.11 & 3.95 & 6.38 & 5.22 \\
\hline 2.90 & 4.06 & 5.73 & 6.38 & 6.38 & 6.38 & 6.38 & $\mathrm{Ac}$ & 5.22 & 2.90 \\
\hline
\end{tabular}

The numbers inside boxes represents $\mathrm{Pu}$ concentration

Figure 8: MOXm-MA-1.45 fuel cell with an FMR $=1.45$

All these different designs of fuel cell were simulated using the Software CASMO-4 through a burn-up of 47.5 GWd/TU, the outcomes are shown in the next section.

\section{Results}

The Table 3 shows the results corresponding to cells simulated without minor actinides incorporated, the mass composition is given for fresh fuel and at a burnup of $47.5 \mathrm{GWd} / \mathrm{TU}$. From the Table 3, it is observed that for the UOX cell the main product is ${ }^{237} \mathrm{~Np}(71.28 \mathrm{~g})$, while for plutonium cells, the production is around $20 \mathrm{~g}$ of ${ }^{237} \mathrm{~Np}$. 


\begin{tabular}{|c|c|c|c|c|c|c|c|c|}
\hline Case $>$ & \multicolumn{2}{|c|}{ UOX-Ref } & \multicolumn{2}{c|}{ MOX (FMR=1.8) } & \multicolumn{2}{c|}{ MOXm (FMR=1.3) } & \multicolumn{2}{c|}{ MOXm (FMR=1.45) } \\
\hline $\begin{array}{c}\text { Burnup } \\
\text { (GWD/TU) }\end{array}$ & $\mathbf{0}$ & $\mathbf{4 7 . 5}$ & $\mathbf{0}$ & $\mathbf{4 7 . 5}$ & $\mathbf{0}$ & $\mathbf{4 7 . 5}$ & $\mathbf{0}$ & $\mathbf{4 7 . 5}$ \\
\hline $234 \mathrm{U}$ & 43.26 & 22.84 & 8.76 & 11.39 & 8.68 & 9.03 & 8.65 & 9.59 \\
\hline $235 \mathrm{U}$ & 5407.89 & 794.18 & 1095.25 & 647.85 & 1085.59 & 519.04 & 1081.52 & 556.80 \\
\hline $236 \mathrm{U}$ & 0.00 & 735.54 & 0.00 & 96.64 & 0.00 & 110.19 & 0.00 & 104.53 \\
\hline $238 \mathrm{U}$ & 126298.84 & 122519.20 & 118806.88 & 116007.46 & 111513.27 & 108855.44 & 110631.74 & 108073.62 \\
\hline $238 \mathrm{Pu}$ & 0.00 & 28.99 & 177.59 & 178.09 & 115.09 & 110.12 & 128.37 & 124.65 \\
\hline $239 \mathrm{Pu}$ & 0.00 & 519.68 & 7127.13 & 3109.80 & 4618.79 & 1399.87 & 5151.99 & 1726.88 \\
\hline $240 \mathrm{Pu}$ & 0.00 & 323.16 & 2900.58 & 2859.44 & 1879.74 & 1760.75 & 2096.73 & 2015.35 \\
\hline $241 \mathrm{Pu}$ & 0.00 & 147.69 & 1041.84 & 1190.41 & 675.17 & 722.25 & 753.11 & 823.66 \\
\hline $242 \mathrm{Pu}$ & 0.00 & 102.37 & 591.96 & 852.31 & 383.62 & 669.98 & 427.91 & 702.39 \\
\hline $\mathbf{2 4 1 \mathrm { Am }}$ & $\mathbf{0 . 0 0}$ & $\mathbf{6 . 3 3}$ & $\mathbf{0 . 0 0}$ & $\mathbf{1 6 1 . 5 7}$ & $\mathbf{0 . 0 0}$ & $\mathbf{8 3 . 4 6}$ & $\mathbf{0 . 0 0}$ & $\mathbf{1 0 1 . 0 8}$ \\
\hline $\mathbf{2 4 2 C m}$ & $\mathbf{0 . 0 0}$ & $\mathbf{2 . 6 1}$ & $\mathbf{0 . 0 0}$ & $\mathbf{2 0 . 1 8}$ & $\mathbf{0 . 0 0}$ & $\mathbf{1 6 . 2 8}$ & $\mathbf{0 . 0 0}$ & $\mathbf{1 7 . 0 3}$ \\
\hline $\mathbf{2 4 4 C m}$ & $\mathbf{0 . 0 0}$ & $\mathbf{7 . 1 1}$ & $\mathbf{0 . 0 0}$ & $\mathbf{5 3 . 2 5}$ & $\mathbf{0 . 0 0}$ & $\mathbf{4 8 . 7 3}$ & $\mathbf{0 . 0 0}$ & $\mathbf{4 7 . 0 8}$ \\
\hline $\mathbf{2 3 7 N p}$ & $\mathbf{0 . 0 0}$ & $\mathbf{7 1 . 2 8}$ & $\mathbf{0 . 0 0}$ & $\mathbf{2 1 . 8 8}$ & $\mathbf{0 . 0 0}$ & $\mathbf{2 0 . 2 7}$ & $\mathbf{0 . 0 0}$ & $\mathbf{1 9 . 8 0}$ \\
\hline TOTAL & $\mathbf{0}$ & $\mathbf{8 7 . 3 3}$ & $\mathbf{0}$ & $\mathbf{2 5 6 . 8 8}$ & $\mathbf{0}$ & $\mathbf{1 6 8 . 7 4}$ & $\mathbf{0}$ & $\mathbf{1 8 4 . 9 7}$ \\
\hline
\end{tabular}

Table 3: The actinides produced (in grams) for all the cases simulated without minor Actinides at a burn-up of UOX and MOX fuels from 0.0 up to $47.5 \mathrm{GWd} / \mathrm{TU}$

The Table 4 show the results for the reference cell and cells that include minor actinides and change in the ratio moderator to fuel in the assembly.

\begin{tabular}{|c|c|c|c|c|c|c|}
\hline Case $>$ & \multicolumn{2}{|c|}{ MOX-MA- $($ FMR=1.8) } & \multicolumn{2}{c|}{ MOXm-MA- (FMR=1.3) } & \multicolumn{2}{c|}{ MOXm-MA-(FMR=1.45) } \\
\hline Burnup & $\mathbf{0}$ & $\mathbf{4 7 . 5 G w d}$ & $\mathbf{0}$ & $\mathbf{4 7 . 5}$ & $\mathbf{0}$ & $\mathbf{4 7 . 5}$ \\
\hline $\mathbf{2 3 7 N p}$ & 264.02 & 154.34 & 288.67 & 147.83 & 288.67 & 187.06 \\
\hline $\mathbf{2 4 1 A m}$ & 27.734 & 142.07 & 30.31 & 72.89 & 30.31 & 96.98 \\
\hline $\mathbf{2 4 2 C m}$ & 0 & 18.93 & 0 & 15.29 & 0 & 17.61 \\
\hline 244Cm & 39.08 & 71.12 & 42.82 & 67.23 & 42.81 & 72.35 \\
\hline TOTAL & $\mathbf{3 3 0 . 8 3 4}$ & $\mathbf{3 8 6 . 4 6}$ & $\mathbf{3 6 1 . 8}$ & $\mathbf{3 0 3 . 2 4}$ & $\mathbf{3 6 1 . 7 9}$ & $\mathbf{3 5 4 . 0}$ \\
\hline
\end{tabular}

Table 4: Initial and Final Inventories in Fuel with 6\% MA

\begin{tabular}{|c|c|c|c|c|c|}
\hline \multicolumn{5}{|c|}{ SimulationCells (in grams of actinides) } \\
\hline & & & 0 GWd/TU & 47.5 GWd/TU & \\
\hline Case & FMR & Cell & Fresh & Discharge & Incineration (g) \\
\hline 1 & Ref. & UOX-Reference & 0 & 87.33 & \\
\hline 2 & 1.8 & MOX-1.8-Ref. & 0 & 256.88 & \\
\hline 3 & 1.3 & MOXm-1.3 & 0 & 168.74 & \\
\hline 4 & 1.45 & MOXm-1.45 & 0 & 184.99 & \\
\hline 5 & 1.8 & MOX-MA-1.8 & 330.86 & 386.46 & -55.6 \\
\hline 6 & 1.3 & MOXm-MA-1.3 & 329.8389 & 303.24 & 26.59 \\
\hline 7 & 1.45 & MOXm-MA-1.45 & 362.23 & 354.01 & 8.22 \\
\hline
\end{tabular}

Table 5: Resume of results for all the different cells Calculated

In the cases 1,2,3 and 4 the MA were not included for the simulation of fuel cell, it is remarkable that the amounts of actinides generated are different for each case, as a reference the UOX fuel generates only $87.33 \mathrm{~g}$ of actinides for a burnup of $47.5 \mathrm{GWd} /$ TU, in comparison the MOX fuel produces as much as three times the amount of the reference fuel, this is mainly due to neutron captures from the plutonium isotopes, which are transmuted to heavier actinides, so the higher concentrations of plutonium in the fuel assembly, the higher amount of actinides is generated (Table 5).

\section{Discussion}

The amounts of actinides in the regular fuel of uranium for a burn-up of $47.5 \mathrm{GWd} / \mathrm{TU}$ was of $87.33 \mathrm{~g}$, the MOX fuel concept was performed, scaling uranium enrichments to plutonium concentrations with the use of the of fissile material ratio defined as FMR, in order to obtain the new fuel cells that include rods with minor actinides integrated. 
For over-moderated cells, the difference between initial and final inventories is marginal but at least, the production of minor actinides during irradiation is avoided.

\section{References}

1. GEN IV International Forum (2015) Global Actinide Cycle International Demonstration (GACID) Project, Annual Report 2015, Mexico.

2. Ramírez SJR (2009) Use of Plutonium in Light Water Reactors and their Neutron Behavior [Utilización de Plutonio en Reactores de Agua Ligera y su Comportamiento Neutrónico]. Tesis Doctoral, Universidad Autónoma del Estado de México, México.

3. Studsvik Scandpower (2004) CASMO-4 a Fuel Assembly Burnup Program, SSP-01/400 e Rev 4.

4. Caballero EM (2015) Análisis de Reducción de Radiotoxicidad Basada en el Reciclado de Actínidos, Tesis Doctoral, Escuela Superior de Física y Matemáticas, IPN, México.

5. Martinez E, Ramirez JR, Alonso G (2015) Actinides recycling assessment in a thermal reactor. Ann Nucl Energy 79: 51-60.

6. Ramirez JR, Alonso G, Martinez E, Castillo R, Palacios JC (2016) Analysis of actinide recycling in a Boiling Water Reactor using CASMO-4/SIMULATE-3. Progres in Nucl Energy 89: 26-38. 